\title{
Unaccompanied and Separated Foreign Children in the Care System in the Western Cape - A Socio-Legal Study
}

\section{J Sloth-Nielsen* and M Ackermann ${ }^{\star \star}$}

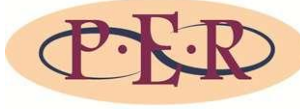

Author

Julia Sloth-Nielsen and Marilize Ackermann

\section{Affiliation}

University of Western Cape and Scalabrini Centre Cape Town South Africa

\section{Email}

jsloth-nielsen@uwc.ac.za marilize@scalabrini.org.za

Date published 30 May 2016

Editor Prof AA du Plessis

How to cite this article

Sloth-Nielsen $\mathrm{J}$ and Ackermann $M$ "Unaccompanied and

Separated Foreign Children in the Care System in the Western

Cape - A Socio-Legal Study" PER / PELJ 2016(19) - DOI

http://dx.doi.org/10.17159/17273781/2016/v19i0a1207

\section{Copyright}

This work is licensed under a Creative Commons Attribution 4.0 International License.

DOI

http://dx.doi.org/10.17159/1727 -3781/2016/v19i0a1207

\begin{abstract}
This article reports on the findings of a study of foreign children accommodated in the care system in the Western Cape, based on fieldwork conducted in child and youth care centres. The objectives of the study were firstly to map and quantify the number and demographics of foreign children placed in all CYCCs across the Western Cape. Secondly, the study aimed to analyse the reasons for children's migration and the circumstances around their placement in residential care institutions in order to establish whether family reunification was possible or desirable. Thirdly, the study explores the sufficiency of efforts made to trace and reunify the children with their families, whether in South Africa or across borders, as the institutional placement of children should not only be a last resort but it should preferably be temporary whilst family-based solutions are sought. Lastly, the documentation status of the children in the study was examined. Recommendations emanating from the research conclude the study.
\end{abstract}

\section{Keywords}

Foreign children; child protection; refugees; asylum seekers; child and youth care centres; children's court. 


\section{Introduction}

The number, demographics and circumstances of unaccompanied and separated foreign children living in South Africa are unknown. Due to scarce and poorly maintained migration data, the prevalence of informal border crossing and the lack of official documentation, little is known about the reality of migration into South Africa, and the situation of unaccompanied child migrants in particular. ${ }^{1}$ The Scalabrini Centre, a nonprofit organisation working with migrant and refugee communities in Cape Town, had been called upon to assist in resolving difficulties experienced by social workers relating to the cases of foreign children who had entered the child protection system through the Children's Court and been placed in care. These requests had been received on an ad hoc basis from a range of social workers. They related amongst other issues to the difficulty in obtaining the necessary documentation, challenges to legalising children's status in South Africa, and difficulties related to contact with the family and possible reunification. The researchers identified the need for a more comprehensive study of the concrete facts and specific challenges faced by foreign children in the child protection system, in order for the researchers to arrive at appropriate recommendations and possible solutions in law and practice to enable these children to better secure their rights.

Hence, this research involved an inclusive survey of all foreign children placed in child and youth care centres (CYCCs) ${ }^{2}$ across South Africa's Western Cape Province. The study aimed to explore the ways in which South African migration law and policy intersect with children's rights. The objectives of the study were firstly to map and quantify the number and demographics of foreign children placed in all CYCCs across the Western Cape. This was necessary in order to obtain a bird's eye view of the magnitude and causes of the incidence of foreign children in the South African child care system, so as to formulate realistic and achievable proposals for the relevant government departments (the Department of Home Affairs, the custodian of migration issues, and the Department of Social Development, responsible for child protection). Secondly, the study aimed to analyse the reasons for children's migration and the

* Julia Sloth-Nielsen. BA LLB (Stel) LLM (Cape Town) LLD (Western Cape). Professor, Faculty of Law, University of the Western Cape. E-mail: jslothnielsen@uwc.ac.za.

** Marilize Ackermann. BA LLB (Stel), LLM (Western Cape). Researcher, Scalabrini Centre, Cape Town. E-mail: marilize@scalabrini.org.za Anderson et al "Unaccompanied and Unprotected".

2 According to s 191 of the Children's Act 38 of 2005, a Child and Youth Care Centre is a facility providing residential care to more than six children outside the child's family environment, and which provides certain therapeutic programmes. 
circumstances around their placement in residential care institutions. This was necessary in order to establish whether family reunification was possible or desirable, or whether alternative durable solutions should be pursued. Thirdly, the study explores the sufficiency of efforts made to trace and reunify the children with their families, whether in South Africa or across borders. This was necessary as a result of the international guiding principle that the institutional placement of children should not only be a last resort but that it should preferably be temporary whilst family-based solutions are sought, in the quest to secure the children's best interests. ${ }^{3}$ Lastly, the children's documentation status and pathways to durable documentation solutions were assessed. The objective of this dimension of the study was twofold: first, the absence of documentation to prove identity leaves children vulnerable to later arrest, detention and deportation once they exit the care system; and second, foreign children who lack documentation may be at high risk of statelessness if they cannot lay claim to the nationality of their country of origin.

\section{Literature review}

At the international level a vast body of literature on child migration is available, such as documentation produced by the United Nations High Commission for Refugees and the International Organisation for Migration. ${ }^{4}$ The literature acknowledges the multidimensional nature of child migration, which can be occasioned by emergencies, natural disasters, war and exploitation, but equally by the search for a better future, either with parents or alone.

No comprehensive study of separated and unaccompanied foreign children in South Africa exists, nor would such a study be feasible to undertake. This is because South Africa does not have an encampment policy for asylum seekers (like for instance Zambia and Zimbabwe), resulting in foreign adults and children alike being accommodated in communities throughout the Republic. A full-blown census would therefore be required to ascertain the full extent of the incidence of foreign separated and unaccompanied children in South Africa.

However, studies have recently been undertaken in Limpopo, Mpumalanga and Gauteng provinces which attempt to shed some light on the protection and migration challenges faced by foreign migrating children, so that appropriate policies can be devised or strengthened. The Coram Children's Legal Centre (based in the UK) and the South African based Legal Resources Centre conducted an EU-funded project, "Ending

See the discussion under $\mathrm{s} 4$ below.

See for instance IOM $2013 \mathrm{https} / / /$ publications.iom.int/books/children-move. 
unlawful deprivation of liberty of women and children in South Africa", from November 2012 - November 2014. ${ }^{5}$ Data was collected through a case management system attached to a legal assistance pilot located in Gauteng and Musina (south of the Zimbabwe border crossing). The pilot project targeted persons in detention and at risk of detention, and focussed in particular on women and children. Most of the 462 pilot project participants were accessed in police stations and shelters in Musina and Johannesburg. The study found, inter alia, that whilst there had been a normative shift away from the detention of children, ${ }^{6}$ research interviews with key stakeholders revealed consistent allegations of the migrant detention of children in more clandestine, remote and hard to access parts of the relevant provinces. Further, the researchers found that the Department of Social Development, along with the police and the Children's Court, have a general practice of referring unaccompanied migrant children to unregistered shelters and issuing temporary care orders, but that other care procedures under the Children's Act 38 of 2005 are not completed. However, insufficient funding has resulted in serious inadequacies in staffing and facilities at the shelters, which are also vulnerable to attacks and raids (both criminal and xenophobic). Although children at the shelters are encouraged and supported to go to school, a lack of money presents a persistent difficulty, and many children are unable to afford learning equipment and pay fees. Furthermore, the poor facilities and migrant children's own priorities, which typically involve the need and desire to work and be mobile, cause many children to run away. Once they leave, these children tend to disappear from the formal legal system, and no efforts are made to track them down. Research findings demonstrated, too, that foreign children in South Africa are systematically excluded from claiming asylum because of a widespread perception amongst law enforcement officials, service providers and the migrants themselves that a person is unable to claim asylum until they are eighteen years old. The study concluded that migrant children in South Africa often find themselves doubly vulnerable: on the one hand they are excluded from the immigration system because they are children; on the other hand they may be turned away from the formal child protection system and services because they have no legal status. The study differed from the present one in two respects: first, it was conducted in provinces outside the Western Cape where different migration trends may be apparent (due to the proximity to Zimbabwe, from which the majority of children in their study originate); and secondly, it had to do mainly with children outside the formal child protection system in unregistered shelters.

Anderson et al "Unaccompanied and Unprotected".

See the discussion of Centre for Child Law v Minister of Home Affairs 20056 SA 50

(T) under $\mathrm{s} 4$ below. 
The situation of migrant children in Limpopo and Mpumalanga has also been the focus of research, in this instance by Save the Children International. ${ }^{7}$ These children are mainly migrants from Zimbabwe and Mozambique.

Shreier of the Refugee Rights Unit at the University of Cape Town published "Working Paper No 4 on Critical Challenges to Protecting Unaccompanied and Separated Foreign Children in the Western Cape: Lessons Learned at the UCT Refugee Rights Unit", ${ }^{8}$ focussing on the key challenges that the Unit has experienced in its case work relating to the protection of unaccompanied foreign children in the Western Cape. The working paper alludes to a wide gap between available policy and legal frameworks and their implementation, with reference to cases brought to the attention of the Unit. The working paper cites cases that bring to the fore one of the key areas of concern, which is that unaccompanied foreign children are not readily able to access the child protection system in the first place, due to a lack of role clarification between social workers and the Department of Home Affairs. The working paper confirms the central problem of lack of documentation. This is particularly acute for children who do not have a claim to refugee status, which needs to be grounded in a well-founded fear of persecution in the country of origin by reasons of race, tribe, religion, nationality, political opinion or membership of a particular social group. ${ }^{9}$ However, whilst citing a couple of cases dealt with by the clinic directly, neither involving children in CYCCs, the working paper does not attempt a comprehensive audit of foreign children in CYCCs in the province.

\section{$3 \quad$ Methodology}

The intention of the researchers was to contact all CYCCs (registered and unregistered) across the province to establish the total number of foreign children accommodated in residential care facilities in order to obtain a comprehensive overview of the situation. Throughout the period 7 January 2015 to 24 February 2015 the researchers made telephonic contact with a total of 50 residential care facilities located throughout the Western Cape to establish if any foreign children were being accommodated there. These facilities included registered and unregistered CYCCs, temporary safe care facilities and a cluster foster care scheme. The 50 CYCCs contacted

7 Save the Children UK 2007 http://www.savethechildren.org.uk/en/docs/childrencrossing-borders.pdf.

8 Schreier 2011 http://www.refugeerights.uct.ac.za/usr/refugee/Working_papers/ Working_Papers_4_of_2011.pdf.

9 See s 3(a) of the Refugees Act 130 of 1998. Also see s 3(b), which applies to a person who flees his or her place of habitual residence as a result of external occupation, foreign domination, or events seriously disrupting public order. 
had a maximum capacity to accommodate 2688 children. Of the total number contacted, 20 facilities were found to accommodate 109 individual foreign children. This means that foreign children represented approximately $4 \%$ of the children in residential care during the research period. Since the number of admissions fluctuates daily, it is estimated that the number of foreign children in care would vary between 100 and 150 at any given point in time.

To all intents and purposes, this is likely to be a complete sample of all foreign children placed in residential care in the Western Cape Province during the relevant period. ${ }^{10}$ Thus, it can be concluded that the total percentage of foreign children in South African care facilities is not overwhelming, and further that the numbers are low enough to suggest that individual solutions should be possible to achieve. Furthermore, the relatively low number of affected children might support a successful approach to the Minister of Home Affairs for a tailor-made solution to regularize the legal status of foreign children in long-term care, since the data does not provide evidence of a flood of foreign children requiring regularisation of their status.

Face-to-face, semi-structured interviews were conducted with residential social workers at each of the facilities which accommodated foreign children, a total of 20 social worker interviewees. No children were interviewed directly. ${ }^{11}$ Surveys were collected in respect of individual children, based on the interviews with the social workers, who accessed the case file of each child. A questionnaire was completed by the researchers on each child, with the aim of capturing empirical data relating to each child's case. The data was captured in such a way as to preserve the anonymity of the child clients. The data recorded pertained to demographic information, the circumstances which gave rise to migration, the family composition and the nature of any contact between the child and the family members who may have a legal duty to care for the child, the efforts that had been made at family tracing and reunification, and the child's documentation status. The overarching goal was to determine if durable solutions, as an alternative to long term placement in institutional care, could be proposed.

10 Seven CYCCs which implement a secure care programme for awaiting trial and sentenced children were contacted to establish the number of foreign children that were accommodated there. A total of three foreign children were found to be detained in three secure care facilities. These cases were not surveyed and are excluded from the study. Further research is needed to establish the reasons for placement of foreign children in secure care facilities.

11 Ethical clearance for the research was obtained from the UWC Research Ethics Committee and the Department of Social Development Research Ethics Committee. 
A limitation of the study was that the researchers relied on interviews with the social workers attached to the CYCCs (known as the residential social workers) and did not consult the children's files directly. Hence the background information may not be comprehensive in all cases.

\section{$4 \quad$ International and domestic legal framework}

The situation of the children covered in this study is governed by multiple and overlapping sources of legal and policy direction. A brief overview of the applicable instruments, international and domestic, is set out next. ${ }^{12}$

\subsection{International legal framework}

At the international level the primary sources of guidance are derived from the international treaties - the United Nations Convention on the Rights of the Child (1989) (UNCRC), and the African Charter on the Rights and Welfare of the Child (1990) (ACRWC), both ratified by South Africa. The UNCRC is considered a critical milestone in the legal protection of refugee- and asylum seeking children, ${ }^{13}$ because in addition to legal provisions in respect of child protection and welfare generally, it established for the first time in international law explicit acknowledgement of the needs and risks of refugee- and asylum seeking children in article 22. In addition, and relevant to this study, there is the provision of rights for children in alternative care (article 20 UNCRC), the right to the periodic review of placement where a child has been placed in care by the competent authority, and rights relevant to the acquisition of a nationality (article 7 UNCRC); article 8 (2) of the UNCRC imposes an obligation upon a state party when a child is [illegally] deprived of some or all of the elements of his identity: the state is then obliged to provide "appropriate assistance and protection with a view to re-establishing speedily his or her identity".

Article 23 of the ACRWC is regarded by scholars as being superior in the scope of its protection to migrant children. ${ }^{14}$ This is because the refugee child whose parents, legal guardians or other relatives cannot be found is to be "accorded the same protection as any other child permanently or

\footnotetext{
12 A more elaborate version of the legal framework is to be found in Schreier 2011 http://www.refugeerights.uct.ac.za/usr/refugee/Working_papers/Working_Papers_4_ of_2011.pdf.

13 Connelly 2015 Int'I J Child Rts.

14 Kaime "Protection of Refugee Children".
} 
temporarily deprived of a family environment for any reason". ${ }^{15}$ Moreover, the provisions are also extended to apply to internally displaced children. ${ }^{16}$

Supplementing the above in the international law sphere are the UNCRC Committee's General Comments, notably General Comment No 6 (2005) dealing with the treatment of unaccompanied ${ }^{17}$ and separated children $^{18}$ outside their country of origin.

In line with the accepted practice of the United Nations High Commission for Refugees, the General Comment requires a best interests determination (BID) of all separated and unaccompanied children, which according to paragraph 20

... requires a clear and comprehensive assessment of the child's identity, including her or his nationality, upbringing, ethnic, cultural and linguistic background, particular vulnerabilities and protection needs.

Subsequent to this, the General Comment advises that the appointment of a guardian (or advisor) as expeditiously as possible serves a key protection for the best interests of the child $^{19}$ (see paragraph 33). In cases where children are involved in asylum procedures or administrative or judicial proceedings, they should, in addition to the appointment of a guardian, be provided with legal representation. The tracing of families should commence as early as possible (paragraph 31(v)).

States should refrain from referring unaccompanied and separated children to asylum procedures if their presence in the territory does not raise the question of international refugee protection needs, according to paragraphs 32 and 67. This is without prejudice to the obligation of States to refer unaccompanied or separated children to relevant procedures serving child protection, such as those foreseen under child welfare legislation. Paragraph 66 of the General Comment decrees that:

15 Article 23(3) of the African Charter on the Rights and Welfare of the Child (1990) (the ACRWC).

16 Article 23(4) of the ACRWC.

17 "Unaccompanied children" (also called unaccompanied minors) are children who have been separated from both parents and other relatives and are not being cared for by an adult who, by law or custom, is responsible for doing so: para 7 of the UN Committee on the Rights of the Child General Comment No 6: Treatment of Unaccompanied and Separated Children Outside their Country of Origin (2005) (General Comment 6).

18 "Separated children" are children who have been separated from both parents, or from their previous legal or customary primary caregiver, but not necessarily from other relatives. These may, therefore, include children accompanied by other adult family members: para 8 of General Comment 6.

19 Para 33 of General Comment 6. 
... asylum-seeking children, including those who are unaccompanied or separated, shall enjoy access to asylum procedures and other complementary mechanisms providing international protection, irrespective of their age.

The accommodation of separated and unaccompanied children in alternative care is covered in paragraph 40 , which elaborates core principles such as the avoidance of deprivation of liberty, the necessity of keeping siblings together, and the desirability of continuity in a child's upbringing. Article 20 of the UNCRC, which established the obligation for a range of alternative care placements to be available so as to avoid the necessity of institutional care, is emphasised in the General Comment.

Paragraph 79 further stipulates that the ultimate aim in addressing the fate of unaccompanied or separated children is to identify a durable solution that addresses all their protection needs, takes into account the child's views and, wherever possible, leads to overcoming the situation of a child's being unaccompanied or separated, such as by family reunification - provided this is in the best interests of the child. Efforts to find durable solutions for unaccompanied or separated children should be initiated and implemented without undue delay and, wherever possible, immediately upon the assessment of a child being unaccompanied or separated. ${ }^{20}$ Family tracing is an essential component of any search for a durable solution. ${ }^{21}$

After a discussion of the exceptional circumstances in which a return to the country of origin is possible and in a child's best interests, ${ }^{22}$ the General Comment proceeds to elaborate the possibility of local integration as follows in paragraph 89:

Local integration is the primary option if return to the country of origin is impossible on either legal or factual grounds. Local integration must be based on a secure legal status (including residence status) and be governed by the Convention rights that are fully applicable to all children who remain in the country, irrespective of whether this is due to their recognition as a

20 Para 80 of General Comment 6 continues: "For all children who remain in the territory of the host State, whether on the basis of asylum, complementary forms of protection or due to other legal or factual obstacles to removal, a durable solution must be sought."

21 Para 80 of General Comment 6.

22 The UNHCR Guidelines on the Protection and Care of Refugee Children (1994) provide that the best interest of an unaccompanied foreign child who has been denied refugee status (or who may not qualify for refugee status) requires that the child not be returned to his or her country of origin unless, prior to the return: a parent has been located in the country of origin who can take care of the child and the parent is informed of all the details of the return; or a relative or other adult caregiver, government agency or child-care agency has agreed to and is able to provide immediate protection and care for the child upon arrival. 
refugee, other legal obstacles to return, or whether the best-interests-based balancing test has decided against return.

Thus, the child's long-term placement has to be considered from the very outset. At that stage, institutional care (such as in a CYCC) should serve as a "very last resort". ${ }^{23}$ While resettlement to a third country is not left out of the reckoning, ${ }^{24}$ it is unlikely to be a real possibility for many of the children whose situations formed the basis of the present study. ${ }^{25}$

The UN Guidelines on the Alternative Care of Children (2009) ${ }^{26}$ form an important corollary to the above. Guideline 11(1) affirms that:

All decisions concerning alternative care should take full account of the desirability, in principle, of maintaining the child as close as possible to his/her habitual place of residence, in order to facilitate contact and potential reintegration with his/her family and to minimize disruption of his/her educational, cultural and social life.

Guideline 12 notes the importance of family-type care:

Decisions regarding children in alternative care, including those in informal care, should have due regard for the importance of ensuring children a stable home and of meeting their basic need for safe and continuous attachment to their caregivers, with permanency generally being a key goal.

Guideline 21 limits the use of residential care to situations where such a setting is specifically appropriate, necessary and constructive for the individual child concerned and in his/her best interests. The deinstitutionalization objective is referred to in Guideline 23, and Guideline 60 reinforces the principle that alternative family care is preferable to residential care. The suggested timeline given for the periodic review of temporary placement is three months, according to Guideline 67, also emphasizing the need for durable solutions to be devised at the earliest opportunity.

\subsection{Domestic legal framework}

The domestic legal position is governed in the first place by the Refugees Act 130 of 1998, which applies to foreign nationals who enter South Africa with the intention to claim asylum. ${ }^{27}$ The Act sets forth three categories of

23 Para 90 of General Comment 6.

24 Para 92 of General Comment 6.

25 The authors have subsequently ascertained from international agencies that South Africa is not a country from which third country resettlement of unaccompanied or separated children is offered.

26 UN General Assembly Guidelines for the Alternative Care of Children UN Doc A/RES/64/142 (2010).

27 Children would not qualify for any available visa category under the Immigration Act 13 of 2002. 
applicants who qualify for refugee status. The first is defined in terms of section 3(a) of the Refugees Act, which states that a person qualifies for refugee status if that person is outside, and unable or unwilling to return to their country of origin, owing to a well-founded fear of being persecuted by reasons of his or her race, tribe, religion, nationality, political opinion or membership of a particular social group, and is unable or unwilling to avail himself or herself of the protection of that country. Section 3(b) of the Refugees Act applies to a person who flees his or her place of habitual residence as a result of external occupation, foreign domination, or events seriously disrupting public order. Section 3(c) of the Refugees Act is of particular importance for children as it allows for the dependent of the asylum seeker to derive similar status. This provision gives effect to the principle of family unity and allows for the refugee family to seek protection together in South Africa. A dependent includes the unmarried, dependent child of the main asylum applicant, or, a child who was formally placed in the care of the main asylum applicant. ${ }^{28}$ The recent decision in Mubake $\mathrm{v}$ Minister of Home Affairs ${ }^{29}$ has extended this definition to include separated children in the care of other asylum seekers such as relatives who are not their parents. In terms of the Refugees Act and Regulations, ${ }^{30}$ an unaccompanied or separated child who appears to qualify for refugee status cannot submit an asylum application without the intervention of a social worker and order of a Children's Court.

The Children's Act 38 of 2005 provides the framework for the placement of children in alternative care. A child who is found to be in need of care and protection may be placed in alternative care by a Children's Court. Ordinarily, according to section 159, orders made by a children's court lapse after 2 years, although they may be extended by such a court. ${ }^{31}$ The case of Centre for Child Law v Minister of Home Affairs ${ }^{32}$ established the link between the asylum and migrant system, and the child protection system. The case decided that unaccompanied foreign children must be dealt with via the then Child Care Act 74 of 1983. Section 150 of the Children's Act, which repealed and replaced the Child Care Act of 1983, contains a list of indicators according to which the child's circumstances must be assessed to determine whether or not he or she is in need of care and protection. Provisions relevant to the review of temporary placements

28 See the definition of "dependent" in $\mathrm{s} 1$ of the Refugees Act.

29 Mubake $v$ Minister of Home Affairs 20162 SA 220 (GP).

30 Section 32 of the Refugees Act and reg 3(5) of the Regulations to the Refugees Act (Gen N R366 in GG 21075 of 6 April 2000).

31 Except in relation to placements in foster care, in respect of which the requirement for a court ordered renewal every 2 years has been temporarily suspended following the judgment In re Minister of Social Development (North Gauteng High Court), unreported case number 21726/2011 of 22 June 2011.

32 Centre for Child Law v Minister of Home Affairs 20056 SA 50 (T). 
after removal by a police official or a social worker ${ }^{33}$ have not withstood constitutional challenge and are being amended. The Children's Act Amendment Bill 13 of 2015 and Bill 14 of 2015 were tabled in Parliament in May 2015 to effect this along with other amendments. At the time of writing the Amendment Bills have not been finalised.

The Department of Social Development's standard operating procedures for foreign unaccompanied and separated children are contained in Guidelines on Separated and Unaccompanied Children Outside their Country of Origin in South Africa (2009) and these set out detailed steps for assisting separated and unaccompanied foreign children, from the identification stage to the assessment and documentation stage, through to temporary safe care, and then finally to formal placement and options for durable solutions. During July 2015 Standing Operating Procedures for the tracing, reunification or alternative care placements of unaccompanied and separated children in South Africa (SOPs) were released by the Department of Social Development. This document does not replace the Guidelines but purports to complement them.

\section{$5 \quad$ Findings of the study}

\subsection{General demographic characteristics}

Almost all the children were placed in CYCCs in the Cape Town Metropole (101) with the few remaining children in close-by towns. None were traced in the coastal areas of the province or the hinterland. The majority $(56 \%)$ of the children was accompanied to South Africa by their parents $(43 \%)$ or other adult family members (13\%). Only $7 \%$ of the children in care decided to cross borders by themselves. 62 children had one or more siblings in care. The ages of the persons in the study varied between 2 and 22 years, ${ }^{34}$ with the largest group being aged between 11 and 15 years (37\%). $60 \%$ were male and $40 \%$ female. All but 3 children of school-going age were attending school in South Africa. ${ }^{35} 12$ of the adult clients (aged over 18 years) had continued with secondary education and therefore qualified for an extension of the care order under section 176 of the

33 Section 152 of the Children's Act 38 of 2005, where this is effected without a court order. In C v Department of Health and Social Development Gauteng 20122 SA 208 (CC) the fact that the court did not need to automatically review the removal before the expiry of 90 days was held to be unconstitutional.

34 It is possible for a person to remain in a CYCC beyond the age of 18 years (until 21 years of age according to $s 176$ of the Children's Act) for the purposes of completing education. The presence of persons older than 21 may be indicative of a sympathetic stance towards children who upon attaining 21 years continue to lack an alternative placement and who often continue to lack documentation too.

35 Of these, two were undergoing testing to determine their educational level and 1 was in a bridging programme. 
Children's Act. 10 had completed Grade 12 (matric) during the placement period. Of these, 3 clients were enrolled in vocational training and 4 clients were enrolled in tertiary education institutions. The lack of documentation, discussed in 5.2 below, was therefore not ultimately an impediment to the children's right to access education.

The research indicates that the children had spent lengthy periods in the public schools system. More than $25 \%$ of them had spent 7 years in a South African school; $11 \%$ had spent 5 to 7 years in school; $18 \%$ had completed 3 to 5 years of schooling; $22 \%$ had attended school between 1 and 3 years.

Defining the nationalities and citizenship of the children presented great difficulty. Firstly, few children had documentation to prove their nationality or to allow an eventual claim to any particular nationality. Secondly, some children's nationalities as recorded on their identification documentation did not correspond with their true countries of origin. This was mostly the case for children in possession of Asylum Seeker Temporary Permits and Refugee Status Permits.

The table below provides an indication of the country of origin of the individual children. It includes the countries of origin of the parents of children born in SA.

Table 1: Country of origin of children

\begin{tabular}{|l|l|}
\hline Country of origin \\
\hline Angola & 9 \\
\hline Burundi & 14 \\
\hline Cameroon & 1 \\
\hline DRC & 46 \\
\hline Kenya & 4 \\
\hline Lesotho & 3 \\
\hline Namibia & 1 \\
\hline Nigeria & 2 \\
\hline Rwanda & 10 \\
\hline Somalia & 4 \\
\hline Tanzania & 2 \\
\hline Uganda & 1 \\
\hline Unknown & 1 \\
\hline Zambia & 1 \\
\hline Zimbabwe & 10 \\
\hline Total & 109 \\
\hline
\end{tabular}


Unlike in the studies reflected in the literature survey, therefore, a minority of the children were Zimbabwean and none were Mozambican. This has implications for the search for durable solutions, as a wide range of countries of origin is reflected in Table 1. Further, whilst a cross-border forum in Limpopo has been established between South African and Zimbabwean social workers in relation to Zimbabwean children crossing the border to that province, which is evidently working quite well, ${ }^{36}$ social workers in the Western Cape Province do not have access to the benefit of such collaboration, which may hamper efforts to find durable solutions. Moreover, the fact that such a large proportion of the children in this study emanate from French-speaking African countries (Burundi, the DRC and Rwanda) places further barriers in the way of family tracing and reunification, since reunification efforts in the country of origin would entail liaison with French-speaking counterparts or relatives.

The research indicates that the majority of the children have been present in South Africa for more than 5 years (61\%). It was found that $22 \%$ have resided in South Africa between 2 and 4 years; $27 \%$ have been present in the country between 5 and 7 years; $13 \%$ between 8 and 10 years, and $21 \%$ have been in South Africa for over 10 years. This tends to indicate a long-term and more permanent presence in the province, in distinction to the more cyclical rotation of children who cross borders more than once between Zimbabwe and South Africa, and Mozambique and South Africa, as found in other studies. ${ }^{37}$

\subsection{Reasons for placement in care}

The research revealed that the reasons for the children's placement in the care system are varied. The largest number of children (36) were placed in CYCCs for socio-economic reasons, which involve for the most part the parents' or caregivers' financial inability to provide for the basic needs of their children. Further to this, 19 children had been abandoned by parents, 16 children had been removed as a result of their being neglected, and nine had been the victim of abuse. Several were orphans, their parents having passed away either in the country of origin or subsequent to migration. 11 had no adult care-giver present in South Africa. In all of the

36 A Standard Operating Procedure (SOP) for the tracing, reunification or alternative care placements of unaccompanied and separated children in South Africa and Zimbabwe has been agreed to by the South African Department of Social Development and the Zimbabwean Department of Social Services, as well as a draft Exit Strategy for Unaccompanied and Separated Children in Limpopo (21 November 2013), which was compiled by the DSD and agreed to by the Zimbabwean counterparts (Southern Hemisphere Consulting Draft Report for System Mapping). 
above instances, the possibilities of family reunification are diminished, which means that other durable solutions may have to be explored, such as local integration in family-type care, as required by the international legal and policy framework.

Furthermore, in contrast to the international policy objective of limiting the duration of institutional placement, once placed in a CYCC the children tended to remain there. As regards the time spent in the alternative care system, just under half of the children had spent between 2 and 4 years in alternative care $(46 \%)$. This is followed by $28 \%$ of the children who had spent between 5 and 7 years in alternative care. $11 \%$ had spent between 8 and 10 years in care and $2 \%$ had been placed for more than 10 years. $13 \%$ of the children had been placed in care for less than a year at the time the survey was conducted. It is concluded that the indicated periods of placement far exceed accepted standards and are contradictory to the principle that children should be placed in institutional care for the shortest possible duration. ${ }^{38}$ The research also suggests that placement with a foster care family is not usually considered as a viable solution by social workers, a fact confirmed in interviews with them. ${ }^{39}$ The overall length of time foreign children spend in CYCCs also points to low rates of family reunification. Indeed, our assessment was that when faced with the crossborder family tracing and reunification of foreign children to the countries of origin of children in CYCCs in the Western Cape, residential social workers generally found themselves at a loss as to how to proceed, as they had no networks or links in those countries to draw upon. ${ }^{40}$

\subsection{Registration, legal status and potential for statelessness}

Documentation is an integral and often overlooked component of child protection. One of the main reasons for this study was to establish the documentation status of foreign children in the child care system, and to assess any possible pathways to regularising their stay in South Africa. Nationally, the Department of Social Development Guidelines require the

38 UN General Assembly Guidelines for the Alternative Care of Children UN Doc A/RES/64/142 (2010) para 14.

39 One reason for this is that the option of placement with a foster asylum seeking family from the child's country of origin is limited by the fact that temporary asylum permits held by foreigners pending determination of their refugee claim must be renewed at intervals of 6 months, whereas a foster care order is for a period of two years. It is not clear why the option of foster care with families who have obtained refugee status or with South African families is not routinely pursued after a set period in the care system, although it could be a reflection of the children's lack of access to formal documentation, as discussed in the next section.

40 This is a reason for the approaches to the Scalabrini Centre which inspired this study in the first place, namely uncertainly amongst social workers as to what they could or should do to find lasting solutions. 
immediate registration and documentation of the child, but are silent on the details. The Guidelines provide no indication of the type of registration that must take place, or the documentation which must be obtained. In fact the Guidelines have no practical effect since no registration mechanism or documentation category is in place. Moreover, the Department is not the custodian of identification documentation, which must be issued by the Department of Home Affairs.

Of the children in this study, only 22 had documentation which identified them (birth certificate and/or passport); ${ }^{41}$ however, neither a birth certificate nor a passport allows legal stay in South Africa. ${ }^{42}$ Only 3 children had legal stay in terms of the Immigration Act 13 of 2002. 56 children (51\%) held documentation issued under the Refugees $\mathrm{Act}^{43}$ which may have expired or been valid, but which would potentially allow temporary legal stay in South Africa. ${ }^{44} 33$ children did not have any documentation allowing their stay in South Africa or providing proof of identity. Of these, the group was split between those with no documentation at all (22\%), those with at least a foreign birth certificate, and those with a "clinic card" or an age estimation issued by a medical officer and the Children's Court. 2 children with Section 22 permits ${ }^{45}$ granted in terms of the Refugees Act also had birth certificates.

Where a child's claim to refugee status is derived from a parent (or other caregiver) ${ }^{46}$ the child is dependent on the main applicant for the finalisation of the asylum application. ${ }^{47}$ Immediately, it is obvious that where a child is separated from the adult applicant - including by virtue of being taken into the care system- difficulties will arise in finalising the application process. 16 children held documentation issued under the Refugees Act as dependents to persons that are not their parents (13 refugee status permits; 3 asylum seeker permits). 8 children had derived either asylum seeker status (5) or refugee status (3) from a parent, but

41 Five children had passports, but two of them contained no valid visas.

42 Put differently, $80 \%$ of the children were not in possession of a birth certificate or another document which would enable access to citizenship.

43 Essential identifying information was incorrectly recorded on $10 \%$ of the documents issued under the Refugees Act.

44 The majority of the children held asylum seeker temporary permits $(27 \%)$. The second largest group held permits which recognized them as refugees (24\%). 19 children held expired asylum seeker permits. Refugee status permits are valid for longer periods, which may explain why only 3 children had expired documents in this category.

45 This is the asylum seekers' permit allowing stay pending the adjudication of an application for refugee status.

46 In line with the recent ruling in Mubake $v$ Minister of Home Affairs 20162 SA 220 (GP).

47 Section 3(c) of the Refugees Act. 
had been since separated from the parent. It is highly probable that these children will experience difficulties in retaining their documentation once they attain their majority due to their separation from the main applicant.

A child's pathway to the nationality of a country depends largely on the documentation status of the parent(s) and birth registration. For 5 individual children, some of whom had been born in South Africa, both parents' nationalities were unknown to social workers. In 26 cases the identities of the fathers were not known. 13 children had parents of mixed nationalities, raising questions about which nationality they may eventually be able to claim.

Furthermore, nationality laws applicable in the country of origin and host country dictate much of the child's ability to become eligible for citizenship. Many questions exist around the nationality of refugees, and the migrant children (as well as the children of refugees) are often at high risk of becoming stateless.

One particular case in this study involved a child born to a father who is foreign and a mother who is a South African citizen, which would have entitled the child to South African citizenship. The child's birth had not been registered, though, and the child's mother had made no efforts to maintain a relationship with the child. The father had a stronger relationship with the child and was considering sending the child to live with his extended family in rural Nigeria. It follows, therefore, that if parents do not register the birth of the child and are not actively involved in securing identification documentation for a child, he or she may eventually lose the ability to access South African citizenship.

Birth on South African soil does not automatically confer South African nationality, and children born to foreign parents, including refugee parents, are considered non-South African citizens. ${ }^{48}$ Non-citizens, including temporary residents, asylum seekers and refugees, have the right to register the births of children born in South Africa. ${ }^{49} 19$ children were born to foreign parents in South Africa, of whom 10 had birth certificates. The births of the other 9 children had not been registered.

48 S 4(3) of the Citizenship Act 88 of 1995: "A child born in the Republic of parents who are not South African citizens or who have not been admitted into the Republic for permanent residence, qualifies to apply for South African citizenship upon becoming a major if- (a) he or she has lived in the Republic from the date of his or her birth to the date of becoming a major; and (b) his or her birth has been registered in accordance with the provisions of the Births and Deaths Registration Act 51 of 1992".

49 See the definition of "non-South African citizen" at reg 1 of the Regulations on the Registration of Births and Death (Gen N R128 in GG 21075 of 26 February 2014). 
A brief assessment points to at least 17 of the children being at high risk of statelessness - having no documentation or means of obtaining documentation which would enable them to claim any nationality. One example of children at risk of statelessness includes 4 children of the same family unit who applied for asylum with the assistance of a social worker. Their nationality was inaccurately captured on the section 22 asylum seeker permit as Mozambican, despite the fact that they originated from a Central African country. As a result of frequent migration across various borders, the absence of documentation, vague recollections of the country of origin and lost contact with their extended family, there appears to be no way of verifying their nationality. They do not appear to qualify for refugee status. Their father is deceased and they have no contact with their mother. Another example of children at risk of statelessness involves 2 children without proof of birth, brought from Angola to South Africa at a young age, and whose parents have both since passed away. The siblings have been placed in care for several years, have no contact with their extended family and have no documentation to enable a claim to Angolan citizenship. Another child was brought to South Africa from either Angola or the DRC at the age of 1 by an unrelated person. He has no recollection of his parents or country of origin. He has been placed in alternative care since the age of 4 . All attempts at finding his family have failed. He has never had any contact with relatives and believes his parents to be deceased. He has no identification documentation and speaks only IsiXhosa and English.

3 clients are the children of an asylum seeker whose application was ultimately rejected in 2008, whereupon he returned to Burundi, leaving his children behind with their stepmother. He died in Burundi in 2010. The children were removed from the care of the stepmother. They have no proof of birth and have been in South Africa for more than 10 years. They have vague recollections of their home country, but they have no documentation to allow them to prove Burundian nationality.

A final example pertains to 3 children of the same family holding refugee status permits which document them as Congolese nationals. They were born in Kenya to a Kenyan mother and Congolese father. They derived refugee status from their mother, who abandoned them at a young age. The father passed away prior to migration. They have no documents to prove their birth or nationality. Without the mother's presence or confirmation of their birth by Kenyan authorities, they are unable to prove their descent. 


\subsection{Migration information}

As a general point, the interviewees (social workers at CYCCs) had very limited knowledge of the geographical regions from which the children came. The survey identified $15(13 \%)$ of the children as separated minors and $27(24 \%)$ as unaccompanied minors at the time of entry to South Africa. The data indicated that 47 children were accompanied by a parent or both parents at the time of entry into the country. In one case, it was not known whether the child was accompanied by anyone. 11 children were accompanied by adults unknown to them, which may point to smuggling (but does not necessarily amount to trafficking). ${ }^{50}$

This information is captured in the following Table:

Table 2: Profile of people accompanying children

\begin{tabular}{|l|c|}
\hline \multicolumn{2}{|l|}{$\begin{array}{l}\text { Entry to South Africa: Who accompanied the } \\
\text { child }\end{array}$} \\
\hline Aunt, Uncle, Sibling (Separated) & 15 \\
\hline Parent(s) (Accompanied) & 47 \\
\hline Born in South Africa & 19 \\
\hline Other children (Unaccompanied) & 2 \\
\hline $\begin{array}{l}\text { Person unknown to child } \\
\text { (Unaccompanied) }\end{array}$ & 11 \\
\hline Alone (Unaccompanied) & 6 \\
\hline $\begin{array}{l}\text { Person known but unrelated to child } \\
\text { (Unaccompanied) }\end{array}$ & 8 \\
\hline Unknown & 1 \\
\hline & 109 \\
\hline
\end{tabular}

Generally, social workers did not know at which border crossing the children had entered. It appears that all the children had crossed by land and none had travelled by plane to South Africa. The reasons for migration were difficult to categorise as these presented a confluence of multiple pull and push factors. Of the 15 children who entered South Africa as separated minors, 7 had been accompanied by extended family members who had the intention of claiming asylum, 5 had accompanied adults for socio-economic reasons, and 3 had entered for unknown reasons. Of the 27 unaccompanied minors, 8 had taken the decision to migrate (7\%). The choice of the children to migrate alone had been motivated by the death of a primary caregiver, the desire to escape from poverty, an abusive domestic situation, or a conflict situation in the country of origin. Of these

50 Two cases of trafficking were being investigated by the police. 
unaccompanied children, 5 came to South Africa for socio-economic reasons and 3 migrated with the intention of claiming asylum.

The largest percentage of children were accompanied by a parent $(43 \%)$ or an adult family member other than a parent (13\%). Without being able to assess the adults' reasons for migration, but taking into consideration the children's documentation status, it is estimated that at least $60 \%$ of the adults accompanying children migrated for the purpose of claiming asylum (whether or not they would qualify for asylum status).

19 children's entries to South Africa were arranged between family members in the country of origin and family established in South Africa. 18 of them were sent to South Africa for socio-economic reasons, which included the availability of better education opportunities (5), the death of the primary caregiver (6), protection from domestic abuse (3) and the imprisonment of the primary caregiver (4). 1 child's entry was arranged to remove him from a conflict zone, following the death of his sole caregiver. A brief assessment indicated that 9 children (4 family units) appeared to qualify for refugee status. An unaccompanied or separated child who appears to qualify for refugee status, and who is found in circumstances which indicate that he or she is in need of care and protection under section 150 of the Children's Act should be brought in front of a Children's Court for an order to be assisted in applying for asylum. ${ }^{51}$ However, numerous obstacles to this exist: Refugee Reception Officers (RROs) have in recent times applied the principle more consistently that children who are in South Africa without a parent are not able to apply for asylum without the intervention of a social worker. Further, only 3 remaining Refugee Reception Offices are open to new applications; these are located in Durban, Pretoria and Musina. Once an order in terms of section 32 of the Refugees Act is obtained, arrangements must be made for minors placed in alternative care to travel to one of these offices, accompanied by a social worker, in order to apply for asylum. Given the geographic location of the Refugee Reception Offices in relation to the Western Cape Province, this represents a major administrative, financial and logistical hurdle for CYCCs and social workers. 2 of the child clients in

51 Section 32 of the Refugees Amendment Act 33 of 2008 refers to the Children's Act in cases where unaccompanied children are found in need of care, as follows: "(1) Any unaccompanied child who is found under circumstances that clearly indicate that he or she is an asylum seeker and a child in need of care contemplated in the Children's Act, 2005 (Act No. 38 of 2005), must- (a) be issued with an asylum seeker permit in terms of section 22; and (b) in the prescribed manner, be brought before the Children's Court in the district in which he or she was found, to be dealt with in terms of the Children's Act, 2005." This amendment is not yet in force as regulations remain to be drafted. It would at least provide some clarity as to the documentation status of children dealt with in terms of the Children's Act and placed in CYCCs. 
our study turned 18 in 2014 and were able to travel to Durban by themselves. Their claims were rejected as unfounded since they could not satisfy the Refugee Status Determination Officer of their knowledge of the region they claimed to originate from (the Eastern $\mathrm{DRC}$ ). During the interview they were expected to show a certain level of knowledge about geographical landmarks and social and political issues affecting the area of former habitual residence, but they had already been residing in South Africa for over 4 years. Arguably, they might have qualified for refugee status if they had been able to claim asylum at the time of their arrival.

The worrying conclusion is that the asylum system is effectively inaccessible to unaccompanied and separated refugee children placed in the Western Cape. When dealing with foreign children, social workers should systematically assess their reasons for migration as soon as possible. If a social worker is not in a position to assess the validity of a child's potential claim to asylum, it is essential that an opinion be obtained from a person who is knowledgeable on refugee law. It is then recommended that children who appear to qualify for refugee status be assisted by social workers to access the Children's Court for an order in terms of section 32 of the Refugees Act as soon as possible so that they can apply for refugee status.

\subsection{Possibilities for family tracing and reunification}

Family tracing and reunification is the preferred option in law and policy for separated and unaccompanied children, where this is in the best interests of the child. This is reflected in the available international law instruments referred to above, as well as in the Department of Social Development's Standard Operating Procedures and Guidelines. However, this option was not possible in many instances for the children in our study. Both parents of 9 children, representing 6 family units, were deceased. For 9 children, representing 7 family units, both parents' whereabouts were unknown and it was not known if they were still alive. Only 19 children had both parents still alive. The information is captured in Table 3:

Table 3: Family tracing

\begin{tabular}{|l|c|}
\hline Parents & $\begin{array}{l}\text { Individual } \\
\text { children }\end{array}$ \\
\hline Both parents deceased & 9 \\
\hline Both parents whereabouts unknown & 9 \\
\hline Mother living and whereabouts known & 59 \\
\hline Mother living and whereabouts unknown & 0 \\
\hline Mothers deceased & 23 \\
\hline
\end{tabular}




\begin{tabular}{|l|c|}
\hline $\begin{array}{l}\text { Unknown if mother is alive and } \\
\text { whereabouts unknown }\end{array}$ & 27 \\
\hline Father deceased & 33 \\
\hline Father living and whereabouts known & 33 \\
\hline Both parents living & 19 \\
\hline
\end{tabular}

A total of 59 children had mothers who were living. Of these, the mothers of 35 children were resident in South Africa and were the primary caregivers of the children prior to placement. The remaining 24 children's mothers resided outside South Africa. The locations of the mothers, as far as this could be established, are indicated on the Table below. Of the 59 children whose mothers are alive and whose places or countries of residence are known, 44 had been able to make contact with their mothers, or were in continued contact. 15 children had no contact with their mothers despite knowing their geographical location. ${ }^{52}$

Table 4: Location of mothers whose whereabouts are known

\begin{tabular}{|l|c|}
\hline Location of mother & Number \\
\hline Western Cape & 29 \\
\hline Gauteng & 6 \\
\hline Angola & 5 \\
\hline Burundi & 3 \\
\hline DRC & 6 \\
\hline Malawi & 1 \\
\hline Mozambique & 4 \\
\hline Spain & 1 \\
\hline Zambia & 1 \\
\hline Zimbabwe & $\mathbf{3 5}$ \\
\hline $\begin{array}{l}\text { Total mothers in South } \\
\text { Africa }\end{array}$ & $\mathbf{2 4}$ \\
\hline $\begin{array}{l}\text { Total mothers outside } \\
\text { South Africa }\end{array}$ & $\mathbf{5 9}$ \\
\hline Total
\end{tabular}

In the cases of 33 children, the whereabouts of their fathers were known or presumed. The fathers of 20 children continued to reside in South Africa, whilst 13 children's fathers were outside South Africa. Of the 33

52 The nature of contact varied between telephonic contact only, visits and telephonic contact, and indirect contact (contact via a third person or messenger). 
cases, 24 children maintained contact with their fathers. In 33 instances the fathers were deceased.

Family reunification efforts were being pursued in 28 cases in the sample, but only where there was a potential caregiver in South Africa. Of the 24 children whose mothers reside abroad, 10 were in telephonic contact with them. Of these, only 2 were deemed to have a good relationship with their mothers, whilst social workers described the remaining relations as "weak". The fathers of 4 children ( 4 family units) were known to reside outside South Africa. In none of these cases was contact maintained.

It was concluded from the interviews with them that the social workers were making real efforts to reunify foreign children with their parents who were resident in South Africa, but that cross-border family reunification was not being pursued. This represents a major challenge to finding durable solutions for foreign children.

Placement with extended family within or outside South Africa was a potential option for some children. Indeed, in 6 cases efforts had been made to trace extended relatives, but the outcomes were still pending.

\section{Conclusions}

The expression "lost in care" seems apposite for the majority of children identified in CYCCs in the Western Cape Province. Whilst the overall number of foreign separated and unaccompanied children is not large relative to the total number of children in formal care in residential institutions, it is apparent, too, that the number is not insignificant, and that the children concerned languish for many years, even decades, in institutional care. A significant number of the children in this study fall into the age groups $16-18$ (19\%) and 11-15 (37\%), which is a crucial period, as documentation must be secured for children who remain in South Africa when they reach 18. While it is difficult to estimate, it is foreseen that many of the children will have no choice but to return to the country of origin once the placement order is no longer valid, since no documentation options are available to them. However, due to the generally lengthy periods spent in the alternative care system, these children will have lost their ability to speak the languages of those countries, will have lost their national identity, and will have lost their sense of belonging.

It is also suggested that the Department of Social Development should consider the possibility of the placement of younger foreign children in the foster care of recognised refugees, so that they can maintain ties to their country of origin. This is reportedly currently not the standard practice of child protection agencies, although legally there is no impediment to 
refugees acting as foster parents. The monthly cost of maintaining a child in care in a residential facility is around R2800, whilst a foster care grant costs the State around R860. ${ }^{53}$ Since foster care is family type placement, it should be preferred to institutional care.

The study showed that half of the children born in South Africa do not have birth certificates. It is therefore imperative that social workers work with parents to ensure that children's births are registered and that the child is in possession of a birth certificate. Finally, since family tracing and reunification efforts do not often appear to bear fruit, it is recommended that durable documentation solutions be explored by the Department of Home Affairs. In this regard, the study strongly recommends that the Department of Home Affairs consider granting permanent residency to unaccompanied and separated foreign children on the grounds of statelessness, or on the basis of special circumstances, as provided for under section 31(2)(b) of the Immigration Act, in cases in which family tracing and reunification efforts have failed, ${ }^{54}$ and for which children no other alternatives exist.

\section{Bibliography}

\section{Literature}

Anderson et al "Unaccompanied and Unprotected"

Anderson $\mathrm{K}$ et al "Unaccompanied and Unprotected: The Systemic Vulnerability of Unaccompanied Migrant Children in South Africa" (Liefaard T and Sloth-Nielsen J 25 Years of the UN Convention on the Rights of the Child: Taking Stock and Looking Forward (Brill Leiden 2016 forthcoming)

Connelly 2015 Int'l J Child Rts

Connelly $\mathrm{H}$ Seeking the Relationship between the UNCRC and the Asylum System Through the Eyes of the Unaccompanied Asylum Seeking Children and Young People 2015 Int'l J Child Rts 52-77

\section{DSD Guidelines}

Department of Social Development Guidelines on Separated and Unaccompanied Children Outside their Country of Origin in South Africa (The Department Pretoria 2009)

\footnotetext{
53 South African Government 2015 http://www.gov.za/services/child-care-socialbenefits/foster-child-grant.

54 Taking into consideration the reasons for migration, the reasons for placement, and the number of years in care, and through setting minimum standards for an assessment of the possibilities of family tracing and reunification.
} 
DSD Standing Operating Procedures

Department of Social Development Standing Operating Procedures for the Tracing, Reunification or Alternative Care Placements of Unaccompanied and Separated Children in South Africa (The Department Pretoria 2015)

IOM Addressing Irregular Migration Flows

International Organisation for Migration Addressing Irregular Migration Flows To South Africa: Profiling Unaccompanied Migrant Children in Musina, Limpopo Province (unpublished report, 2014, copy on file with the authors)

Kaime "Protection of Refugee Children"

Kaime $\mathrm{T}$ "The Protection of Refugee Children under the African Human Rights System: Finding Durable Solutions in International Law" in SlothNielsen J (ed) Children's Rights in Africa: A Legal Perspective (Ashgate London 2008) 183-197

Southern Hemisphere Consulting Draft Report for System Mapping Southern Hemisphere Consulting Draft Report for System Mapping of the Protection of Unaccompanied and Separated Migrant Children in South Africa (submitted to Save the Children South Africa, 26 February 2016, copy on file with the authors)

\section{Case law}

C v Department of Health and Social Development Gauteng 20122 SA 208 (CC)

Centre for Child Law v Minister of Home Affairs 20056 SA 50 (T)

In re Minister of Social Development (North Gauteng High Court) unreported case number 21726/2011 of 22 June 2011

Mubake v Minister of Home Affairs 20162 SA 220 (GP)

\section{Legislation}

Births and Deaths Registration Act 51 of 1992

Child Care Act 74 of 1983

Children's Act 38 of 2005

Citizenship Act 88 of 1995 
Immigration Act 13 of 2002

Refugees Act 130 of 1998

Refugees Amendment Act 33 of 2008

International instruments

African Charter on the Rights and Welfare of the Child (1990)

Convention on the Rights of the Child (1989)

UN Committee on the Rights of the Child General Comment No 6: Treatment of Unaccompanied and Separated Children Outside their Country of Origin (2005)

UN General Assembly Guidelines for the Alternative Care of Children UN Doc A/RES/64/142 (2010)

UNHCR Guidelines on the Protection and Care of Refugee Children (1994)

\section{Government publications}

Children's Act Amendment Bill B13 of 2015 (published in GG 38703 of 17 April 2015)

Children's Act Second Amendment Bill B14 of 2015 (published in GG 38703 of 17 April 2015)

Regulations to the Refugees Act (Gen N R366 in GG 21075 of 6 April 2000)

Regulations on the Registration of Births and Death (Gen N R128 in GG 21075 of 26 February 2014)

\section{Internet sources}

IOM 2013 https://publications.iom.int/books/children-move

International Organisation for Migration 2013 Children on the Move https://publications.iom.int/books/children-move accessed 10 April 2015

Save the Children UK 2007 http://www.savethechildren.org.uk/en/docs/children-crossing-borders.pdf 
Save the Children UK 2007 Children Crossing Borders: Report on Unaccompanied Minors Who have Travelled to South Africa http://www.savethechildren.org.uk/en/docs/children-crossing-borders.pdf accessed 15 November 2015

Schreier 2011 http://www.refugeerights.uct.ac.za/usr/refugee/Working_papers/Working_ Papers_4_of_2011.pdf

Schreier T 2011 Critical Challenges to Protecting Unaccompanied and Separated Foreign Children in the Western Cape: Lessons Learned at the UCT Refugee Rights Unit, University of Cape Town Refugee Rights Unit http://www.refugeerights.uct.ac.za/usr/refugee/Working_papers/Working_ Papers_4_of_2011.pdf accessed 9 March 2015

South African Government 2015 http://www.gov.za/services/child-caresocial-benefits/foster-child-grant

South African Government 2015 Foster Child Grant http://www.gov.za/services/child-care-social-benefits/foster-child-grant accessed 27 May 2015

\section{List of Abbreviations}

ACRWC

BID

CYCC

DSD

Int'I J Child Rts

IOM

RROs

SOPs

UN

UNCRC

UNHCR
African Charter on the Rights and Welfare of the Child Best interests determination

Child and youth care centres

Department of Social Development

International Journal on Children's Rights

International Organisation for Migration

Refugee Reception Officers

Standing Operating Procedures for the tracing, reunification or alternative care placements of unaccompanied and separated children in South Africa United Nations

United Nations Convention on the Rights of the Child United Nations High Commissioners for Refugees 